Bangl. J. Vet. Med. (2006). 4 (2): 107-115

\title{
RESPONSES OF THE BLACK BENGAL GOAT (CAPRA HIRCUS) TO PMSG AND SURGICAL EMBRYO RECOVERY WITHIN MOET TECHNIQUE
}

\author{
M. O. Faruk ${ }^{1}$, F. Y. Bari, M. Shamsuddin, M. G. S. Alam and M. F. Islam²
}

Department of Surgery and Obstetrics, Faculty of Veterinary Science, Bangladesh Agricultural University, Mymensingh-2202, Bangladesh

\begin{abstract}
The aim of the present study was to determine the responses of Black Bengal Goat following synchronization with alfaprostol, superovulation with PMSG and embryo collection with surgical procedure. This research work was carried out at the Department of Surgery and Obstetrics, Bangladesh Agricultural University (BAU) during the period from January to December 2001. Three Flushing schedules have been carried out in one-year time consisting of 5 donor and 4 recipients in Flush I, 2 donors and 4 recipients in Flush II, and 4 donors and 3 recipients in Flush III. The donors as well as the recipients were synchronized with Gabbrostim ${ }^{\circledR}$ (Alfaprostol, VETEM, Italy) at the dose rate of 2-mg equivalent to $1 \mathrm{ml} /$ goat. Among 11 donors only 6 donors responded following first injection, but all donor responded with second and third injection of Gabbrostim $^{\circledR}$. The mean time of onset of oestrus and duration of oestrus in donor were $29.9 \pm 9.20 \mathrm{~h}, 50.0 \pm 5.94 \mathrm{~h}, 47.8 \pm$ $4.05 \mathrm{~h}$ and $20.9 \pm 5.10 \mathrm{~h}, 27.9 \pm 1.19 \mathrm{~h}, 29.4 \pm 1.36 \mathrm{~h}$ respectively. Among 11 recipient does, only 6 responded following first injection of Gabbrostim, while that of second injection was 9. The mean time of onset of oestrus and duration of oestrus were $28.6 \pm 9.69 \mathrm{~h}, 40.1 \pm 8.95 \mathrm{~h}$ and $17.1 \pm 5.05 \mathrm{~h}, 22.5 \pm 3.45 \mathrm{~h}$ respectively. All 9 recipients responded in third injection and the mean time of onset of oestrus and duration of oestrus were $39.9 \pm 5.06 \mathrm{~h}$ and $27.4 \pm 1.32 \mathrm{~h}$ respectively. In all flushing schedules, superovulation was performed using PMSG (Folligon ${ }^{\circledR}$, Intervet International B.V, Holland) at the dose rate of 900 IU, $800 \mathrm{IU}$ and $700 \mathrm{IU}$ respectively. Both natural service and AI was performed to fertilise the ovum after onset of oestrus. The superovulatory response was determined by counting the number of corpora lutea (CL) during collection of embryos. The percent of superovulatory donor goats were 100,50 and $25 \%$ respectively. The mean number of ovulation was $13.6 \pm 3.6,10.5$ \pm 8.5 and $3.5 \pm 3.2$ respectively. The embryos were collected surgically by using $50 \mathrm{ml}$ Phosphate buffer saline (PBS). The embryos were counted and graded under stereomicroscope. The embryo collection rates varied from $0-100 \%$. The recovered embryos were of $100 \%$ fertile. The total number of embryos recovered was 4,8 and 8 with the percent of recovery 6,38 and $61.5 \%$ respectively. In Flush I among 4 recovered embryos, 3 were Grade 1 morula and the rest embryo was Grade 2 late morula. In Flush II among 8 recovered embryos, 7 were Grade 2 early morula and rest embryo was Grade 2 late morula. In Flush III among 8 recovered embryos, 5 were Grade 2 morula and rests 3 were Grade 2 late morula.
\end{abstract}

Key words: Black Bengal goat, PMSG, embryo, MOET

\section{INTRODUCTION}

The Black Bengal goats are the predominant goat breed in Bangladesh and are very easy to rare. It is mainly used for meat, milk and leather production. But the problems of Black Bengal goat breed are their small body sizes (average body wt is $15 \mathrm{~kg}$ ) and high fat content in the meat, both intra-muscular and subcutaneous. The people dislike the high fat content, mainly due to three-reason taste, wastefulness and health. Saturated fat content in the food has been found to be associated with the incidence of several increased chronic degenerative diseases involving the digestive system, circulatory system and heart (Keys et al., 1986).

To increase the body size and to improve the economic traits in goat it is necessary to bred the top quality buck with top quality she-goat. However, the mean ovulation rate of Black Bengal goat is two. Through natural breeding this will be a long-term process to get the increased number of goat with high economic traits. Superovulation within the MOET technique is mainly performed with the object of increased ovulation rate and hence increased supply of high quality embryos for transfer to increase the high quality offspring.

Present address: ${ }^{1}$ Livestock Training Institute, Tilagor, Sylhet, E-mail address: mofaruk05@yahoo.com, ${ }^{2}$ Department of Medicine and Surgery, Dinajpur Government Veterinary College, Basher Hat, Dinajpur. 
Therefore, if multiple ovulation and embryo transfer technique be applied within the breeding programme, it will take less time to increase the selection intensity through the mother line. Studies in sheep indicated that genetic gain per generation of selection could be doubled if each ewe supply 10 offspring per breeding year (Smith, 1986 and Bari et al., 1999). Several researches have been conducted in Europeans countries in goats for better responses and yield of transferable embryos. For example, choice of better gonadotrophins (Armstrong and Evan 1983; Agrawal, 1986; Baril et al., 1988 and Goel et al., 1991), dose of gonadotrophins (Agrawal and Bhattacharyya, 1982), dose and device of synchronizing agent (Ishwar and Pandey, 1988; Nandy et al., 1990; Martemucci, 1992), mating system (Tervit et al., 1986; Baril et al., 1989), transfer of embryos (Armstrong and Evan, 1983; Nagashima et al., 1987; Baril et al., 1989; Flores- Foxworth, 1997) and synchrony of oestruses between donor and recipients (Armstrong and Evan, 1983; Bondurant, 1986; Lewis, 1996). No published work has been reported on multiple ovulation and embryo transfer in Black Bengal goat in Bangladesh. Therefore the present work was designed to observe the responses of Black Bengal goat following superovulatory with PMSG and embryo recovery with surgical embryo recovery method.

\section{MATERIALS AND METHODS}

This study was conducted at the Department of Surgery and Obstetrics, BAU during the period from January to December 2001 under the BAURES project, Evaluation of Multiple Ovulation and Embryo-Transfer Technique in Black Bengal goat in Bangladesh. The eleven Black Bengal goat of 1 and 2 years old, weighing 10-15 kg were flushed as a donor in three times (Flush I, 5 Flush II 2, and Flush III 4) in one years time within the MOET treatment. The number of recipient does was also 11 (Flush I 4, Flush II, 4 and Flush III, 3). The goats were housed in well-ventilated, concrete floor; house with adequate light. The goats were fed sufficient green grass and a concentrate mixture containing equal amounts of wheat bran, crushed wheat, soybean bran, maize grain at the added with $2 \%$ iodinated salt and $1 \%$ vitamin and mineral premix at the rate of $0.5 \mathrm{~kg} / \mathrm{head}$. The goats were acclimatized for 3 months and checked for normal cycle before giving treatment.

\section{Synchronization of oestrus}

Synchronization of oestrus was done with two intramuscular injection of $1 \mathrm{ml}$ equivalent to $2 \mathrm{mg}$ Gabbrostim ${ }^{\circledR}$ (Alfaprostol, VETEM SPA, Porto Empedocle, Italy) at 11 days apart in both donor and recipient goats. The donor and recipient goats were observed for signs oestrus at $4 \mathrm{~h}$ interval from $700 \mathrm{~h}$ to $2000 \mathrm{~h}$. Onset of oestrus was detected on the basis of the behavioral and clinical signs.

\section{Superovulatory response}

Three doses of PMSG (Folligon ${ }^{\circledR}$, intervet International B.V., Boxmer, Netherlands) 900 IU (n = 5), 800 IU (n $=2)$ and $700 \mathrm{IU}(\mathrm{n}=4)$ were used for superovulation. The superovulation treatment was initiated at Day 10 or Day 11 of the oestrous cycle (Day $0=$ day of oestrus). A luteolytic dose of synthetic prostaglandin $F_{2} \alpha$ (alfaprostol, Gabbrostim $^{\circledR}, 2$ mg, VETEM S.P.A, Porto Empedocle, Italy) was injected intramuscularly 48 hours after injection of PMSG to induce oestrus.

\section{Natural service and artificial insemination}

Both natural service and artificial insemination were performed to fertilize the superovulated ovum. The donor goats were inseminated at 6 hour after the onset of oestrus. Then the goats were allowed to serve by the buck at about 6 hour after insemination.

\section{Embryo collection}

Embryos were collected from donor goats by surgical embryo collection method on Day 6 or 7 after natural service and AI. A sedative, chlorpromazine hydrochloride (Largactil ${ }^{\mathbb{B}}$, Rhone-Poulenc, Bangladesh), was injected IM at the dose rate of $0.1 \mathrm{mg} / \mathrm{kg}$ body weight approximately 15-30 minutes before surgery. The rear half of the abdominal wall, anterior to the udder, was clipped, shaved, scrubbed with antiseptic solution (Hexisol ${ }^{\circledR} ; 0.5 \%$ chlorhexidine gluconate, ACI, pharmaceuticals, Ltd, Bangladesh) and dried. Paravertebral nerves were blocked by injecting $12 \mathrm{ml}$ of $2 \%$ lignocaine hydrochloride, $4 \mathrm{ml}$ in last thoracic, $3 \mathrm{ml}$ in both first and second lumbar and $2 \mathrm{ml}$ in third lumbar vertebral spinal nerve (Jasocaine ${ }^{\mathbb{B},}$ Jayson pharmaceuticals, Ltd, Bangladesh). The skin and underline tissue was desensitized by infiltrating $5 \mathrm{ml}$ of $2 \%$ lignocaine hydrochloride. The donor goat was suspended in head down position in the wooden made cradle. The abdomen was covered with a sterile towel cloth attached with towel clips. A 1-2 inch para-midline incision was made immediately cranial to the udder using regional paravertebral and local anaesthesia. Reproductive tracts were exteriorized 
Responses of goat to PMSG and surgical embryo recovery

starting from the cervix to ovaries and anchored there to avoid repeated handling. Ovaries were examined and the number of ovulation was counted by counting the number of corpora lutea. After holding the uterus, a bone pin was used to puncture the uterine horn about 1-2 inch below the external bifurcation. An 8 french gauge foley catheter with the stilette was inserted into the base of uterine horn through the punctured wound. The stilette was taken out and the balloon of the foley catheter was inflated with 5-ml air. A puncture wound was made in the tip of the horn using a blunted $19-\mathrm{G}$ needle attached to a $50 \mathrm{ml}$ syringe containing $50 \mathrm{ml}$ flushing medium (PBS solution containing a balanced salt solution, supplemented with a protein source, BSA and antimicrobials). After flushing through the 50-ml medium the uterine lumen was completely evacuated by blowing through 50-ml air using same needle and syringe. A total of 100-150 ml of medium was used in two to three flushes of individual horn. The flushing medium containing the embryos was collected into a pre-warmed sterile pot. The flushing procedure was then repeated for the other horn. The tip of the uterine horn was placed back into the abdominal cavity and the foley catheter removed carefully after deflation of the balloon. All the instruments were removed from the abdomen and the wound was sutured aseptically.

\section{Post collection care and management}

The skin wounds of all donors goats were covered with benzoin seal. The donor goats were immediately injected with $2 \mathrm{mg}$ alfaprostol and 0.5 gm streptomycin with 5 lac penicillin (Streptopen ${ }^{\mathbb{B}}, 0.5 \mathrm{gm}$, Renata Animal Health, Dhaka, Bangladesh) to induce oestrus and protect from microbial infection.

\section{Selection and grading of collected embryos}

The flushed out concentrated medium was divided in to two portion and placed in a searching petridish (100$\mathrm{mm}$ diameter, CORNING ${ }^{\circledR}$ New York, USA) and examined under a stereomicroscope (20X, Binocular Stereomicroscope ${ }^{\circledR}$, XTS-110, China) to visualize the embryos. The identified embryos were individually picked up with a micropipette controller (Assistent Micro Classic ${ }^{\circledR}$ No. 558, Kart Hecht GmbH \& Co. KG, Germany) and placed in a small sized petri dish $\left(35 \mathrm{~mm}\right.$ diameter, FALCON ${ }^{\circledR}$, Betcon Dickinson Company, Japan) containing fresh, filtere-sterilized $\left(0.22 \mu \mathrm{m}\right.$ pore size, Minisart ${ }^{\circledR}$, Minitub GmbH, Tiefenbach b. Landshut, Germany), medium. The embryos were washed 4 times in the same way and evaluated subsequently. The embryos were classified in four groups according to the method described by Flores- Foxworth (1997) and Bari et al.(1999). Grade 1- the embryo was nearly perfect with more than $98 \%$ of the cell mass active and healthy, Grade 2- about 70 to $98 \%$ of the cell mass was active and healthy and some extruded blastomeres were found, Grade 3- a poor quality embryo with less than $70 \%$ of the cell mass active and healthy and several extruded blastomeres were present, Grade 4- degenerated embryos with no active cell mass and distinct plasma membrane.

The data were analyzed statistically by the paired t-test.

\section{RESULTS AND DISCUSSION}

\section{Synchronization}

The time of onset of oestrus and the duration of induced oestrus after injection of Alfaprostol within three Flushing schedules are shown in Table 1 and 2.

Table 1. Effect of alfaprostol on the onset of oestrus and duration of oestrus in donors and recipients in Flush I, II and III. (mean \pm s.e.) h

\begin{tabular}{|lllll|}
\hline $\begin{array}{l}\text { Flush I + Flush II } \\
+ \text { Flush III }\end{array}$ & No. of donor injected & No. of donor responded & Time of onset of oestrus & Duration of oestrus \\
\hline $\begin{array}{llll}1^{\text {st }} \text { injection } \\
2^{\text {nd }} \text { injection }\end{array}$ & 11 & $\begin{array}{l}6(54.5 \%) \\
11(100 \%)\end{array}$ & $\begin{array}{l}29.9 \pm 9.20 \\
50 \pm 5.94\end{array}$ & $20.9 \pm 5.10$ \\
\hline $\begin{array}{l}\text { Flush I + Flush II } \\
+ \text { Flush III }\end{array}$ & $\begin{array}{l}\text { No. of recipient } \\
\text { injected }\end{array}$ & $\begin{array}{l}\text { No. of recipient } \\
\text { responded }\end{array}$ & Time of onset of oestrus & Duration of oestrus \\
\hline $1^{\text {st }}$ injection & 11 & $6(54.5 \%)$ & & \\
$2^{\text {nd }}$ injection & 11 & $9(81.8 \%)$ & $28.6 \pm 9.69$ & $17.1 \pm 5.05$ \\
\hline
\end{tabular}


Table 2. Comparison of onset of oestrus and duration of oestrus between donor and recipient does following $3^{\text {rd }}$ injection of prostaglandin (mean \pm s.e.) $\mathrm{h}$

\begin{tabular}{|llllll|}
\hline Donor/Recipient & $\begin{array}{l}\text { No. of doe } \\
\text { injected }\end{array}$ & $\begin{array}{l}\text { No. of doe } \\
\text { responded }\end{array}$ & $\begin{array}{l}\text { Time of onset } \\
\text { of oestrus }\end{array}$ & Duration of oestrus & $\begin{array}{l}\text { Significance of } \\
\text { difference }\end{array}$ \\
\hline Donor & 11 & $11(100 \%)$ & $47.8 \pm 4.05$ & $29.4 \pm 1.36$ & NS \\
Recipient & 9 & $9(100 \%)$ & $39.9 \pm 5.06$ & $27.4 \pm 1.32$ & \\
\hline
\end{tabular}

*NS= Not significant.

In donor goats, the percentage of goats showed oestrus after 1st, 2nd and 3rd injections were 54.5, 100 and $100 \%$ respectively. The mean time of onset of oestrus was $29.9 \pm 9.20$ (s.e.), $50 \pm 5.94$ (s.e.), $47.8 \pm 4.05 \mathrm{~h}$ (s.e.) respectively. The mean times of duration of oestrus were $20.9 \pm 5.10$ (s.e.), $27.9 \pm 1.19$ (s.e.) and $29.4 \pm 1.36 \mathrm{~h}$ (s.e.) respectively. In recipient goat, the percentage of goats showed oestrus and the mean time of onset of oestrus were $54.5,81.8$, and $100 \%$, respectively following first, second and third injection of alfaprostol. The mean time of onset of oestrus and duration of oestrus was $28.6 \pm 9.69$ (s.e), $40.1 \pm 8.95$ (s.e) and $39.9 \pm 5.06 \mathrm{~h}$ (s.e) and $17.1 \pm 5.05$ (s.e), $22.5 \pm 3.45$ (s.e) and $27.4 \pm 1.32 \mathrm{~h}$ (s.e) respectively.

In paired t-test, there was no significant difference between the donor and recipient goats on the onset of oestrus and duration of oestrus after third injection of prostaglandin, where the donors only had PMSG injection (Table 2). The plasma progesterone concentrations plummeted to below basal levels after the alfaprostol injection (Figure $1 \& 2$ ).

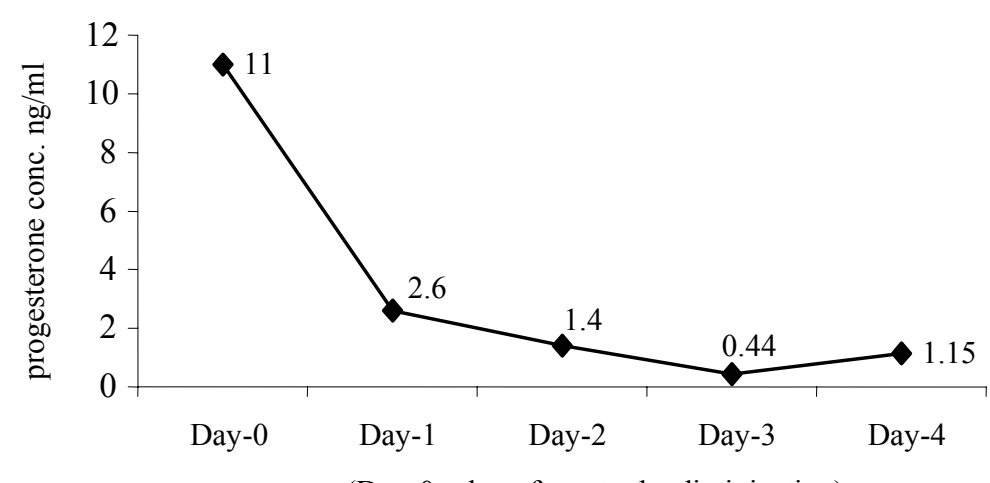

(Day- $0=$ day of prostaglandin injection)

Fig. 1. Plasma progesterone concentration in does treated with alfaprostol 


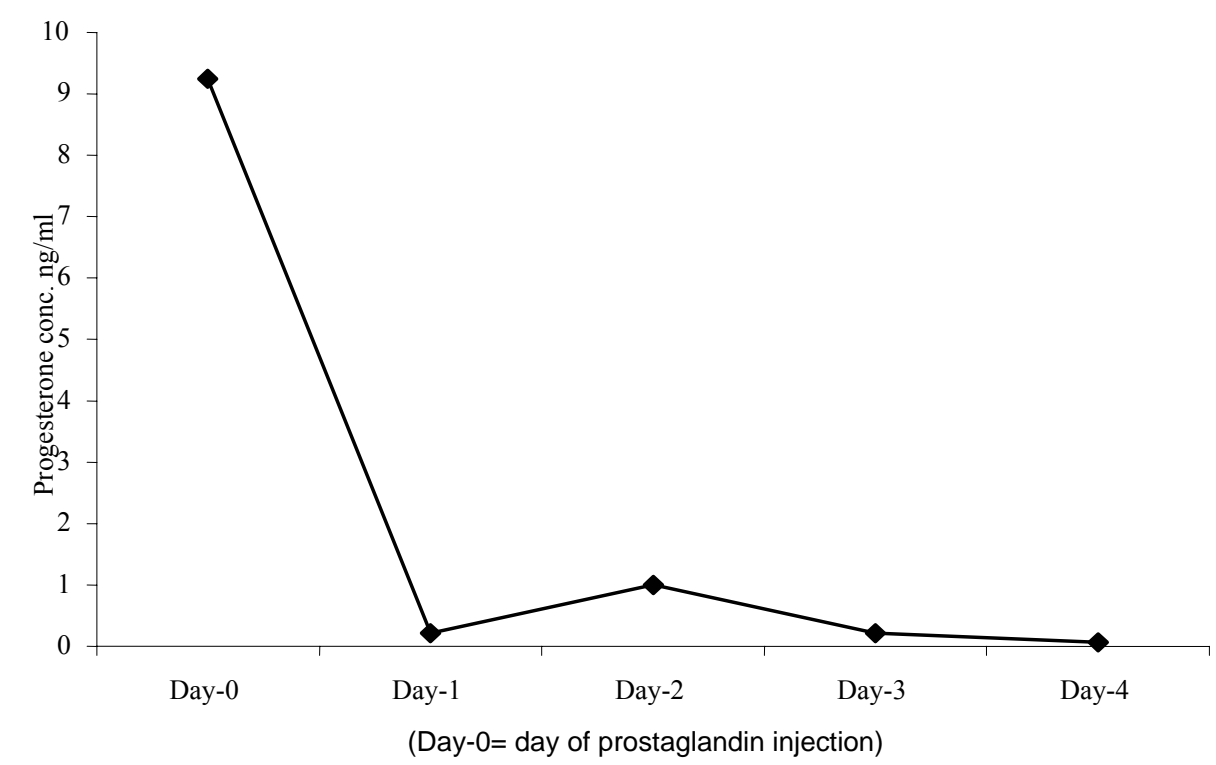

Fig.2. Plasma progesterone concentration in does treated with alfaprostol

\section{Superovulation}

Effects of PMSG on superovulatory response and embryo yield of Black Bengal goats is shown in Table 3.

Table 3. Effects of PMSG and surgical embryo recovery procedures in the Black Bengal Goat (mean \pm s.e.)

\begin{tabular}{|llll|}
\hline Parameters & $\begin{array}{l}\text { Flush I } \\
(900 \text { IU PMSG) }\end{array}$ & $\begin{array}{l}\text { Flush II } \\
(800 \text { IU PMSG) }\end{array}$ & $\begin{array}{l}\text { Flush III } \\
\text { (700 IU PMSG) }\end{array}$ \\
\hline Incidence of superovulation $\geq 3$ & $5 / 5(100 \%)$ & $1 / 2(50 \%)$ & $1 / 4(25 \%)$ \\
superovulation/donor goat & $13.6 \pm 3.6$ & $10.5 \pm 8.5$ & $3.5 \pm 3.2$ \\
(mean \pm s.e.) & $(4-25)$ & $(2-19)$ & $(5-8)$ \\
Embryo recovery percentage & $6(4 / 64)$ & $38(8 / 21)$ & $61.5(8 / 13)$ \\
& $(0-100 \%)$ & $(0-50 \%)$ & $100 \%$ \\
Percentage of fertilized embryos $)$ & 100 & 100 & 100 \\
Quality of embryos & Grade 1 morula-3 & Grade 2 early morula-7 & Grade 2 morula-5 \\
& Grade 2 late morula- 1 & Grade 2 late morula-1 & Grade 2 late morula-3 \\
\hline
\end{tabular}




\section{Superovulatory response}

Based on $\geq 3$ superovulation rate, the percent of superovulatory donor goats were, 100,50 and $25 \%$ following stimulation with 900, 800 and 700 I.U. PMSG, respectively. The ovulation rate varied from 2-25. The mean number of superovulation in 900, 800 and 700IU PMSG were 13.6 $\pm 3.6,10.5 \pm 8.5$ and $3.5 \pm 3.2$ respectively.The superovulatory response was higher in Flush I with 900 IU Folligon $^{\circledR}$ (PMSG), $(13.6 \pm 3.6)$ compared to 800 and $700 \mathrm{IU}$ PMSG.

\section{Embryo recovery}

The embryo recovery rates varied from $0-100 \%$. The total number of embryo recovered were 4,8 and 8 with the percent of recovery 6,38 and $61.5 \%$ in Flush I, II and III, respectively. The recovered embryos were of $100 \%$ fertile.

\section{Embryo quality}

In Flush I among 4 recovered embryos, 3 were Grade 1 quality morula and the rest embryo was Grade 2 quality late morula. In Flush II among 8 recovered embryos, 7 were Grade 2 quality early morula and rest embryo was Grade 2 quality late morula. In Flush III among 8 recovered embryos, 5 were Grade 2 quality morula and rest 3 was Grade 2 quality late morula. In most of the cases no embryos were transferred to the recipients due to unavailability of recipients correspond to the donors oestrus or unavailability of embryos from the donor corresponds to the recipient in oestrus. In Flush II among 8, a total of 3 embryos were transferred, 2 in right horn and 1 in left horn. However, the recipient showed heat within 3 weeks of transfer.

Synchronization of oestrus is usually performed to have the entire animal in oestrus and offspring at the same time. Within a MOET programme, synchronization of oestrus gives the opportunity to have the donor and recipient animals at the same stage of cycle at the time of embryo transfer which is essential to achieve maximum survival of embryos (Moor and Rowson, 1966), since the degree of synchrony is one of the factors influencing the success of embryo transfer (Torres et al., 1987). Synchronization of oestrus with synthetic prostaglandins resulted in 100 percent donor were in oestrus and 41.66 percent conception/pregnancy rate (Pandiya and Rathor, 1986) within MOET programme. The injection of cloprostenol resulted in $87.5 \%$ donor goat in heat. The mean time of onset of oestrus was $38.4 \pm 0.3 \mathrm{~h}$ (s.e.) and duration of oestrus was $40.8 \pm 0.2 \mathrm{~h}$ (s.e.) respectively (Armstrong et al., 1983b).

In the present study, Donor and recipients goats were synchronized with Alfaprostol. The percent of donor goats showed heat were 54.5, 100 and $100 \%$ following first time, second time and third time injection of Alfaprostol. The mean time of onset of oestrus in donor and recipient varied from $29.9 \pm 9.20$ (s.e.) to $50 \pm$ $5.94 \mathrm{~h}$ (s.e.) and $28.6 \pm 9.69$ (s.e.) to $40.1 \pm 8.95 \mathrm{~h}$ (s.e.) respectively. This mean time of onset of oestrus in donor after Alfaprostol injection is similar to some published works (Armstrong et al., 1983b; Bretzlaff et al., 1983; Alam et al., 1989; Biswas et al., 2000). However, this is lowered than those reported by Pandey and Ishwar (1990) and higher than those reported by Holtz and Sohnrey (1992) and Perera et al. (1978). The discrepancy could be due to the fact that although synthetic prostaglandins were used in all works to synchronize the oestrus in goats, however, they were the products of different laboratories of having different qualities and doses. Like the mean time of onset of oestrus in donor and recipients goats, the mean time of duration of oestrus in donor goat were comparable to some of the published work (Holtz and Sohnrey, 1992; Martemucci, 1992) and dissimilar to some of the works (Pandey and Ishwar, 1990; Armstrong et al., 1983b; Biswas et al., 2000). The explanation of this dissimilarity of duration of oestrus is similar to mean time of onset of oestrus, however there were also some limitations at the beginning of the work about the carefulness of observation on the animals. In recipient goats both mean time of onset of oestrus and mean time of duration of oestrus was lower compared to donor. It is difficult to explain why in recipients the mean time of onset of oestrus was lower. The recipient's chosen were comparatively weaker than donor. Also there could be possibility of error in counting the hour. Further work is going on. These will elucidate the explanation.

In paired t-test, the absence of difference between the donor and recipient on the onset of oestrus and duration of oestrus following third injection of prostaglandin indicates that PMSG did not have any influence on the onset of those parameters.

MOET has the potential to speed up the process of genetic improvement by increasing selection intensity through the female line, but for this potential to be realized it requires a high superovulatory response. Among a number of factors, choice of gonadotrophin for superovulation of donor animal is the first important one, which 
can affect the responses. It is desirable to have preparation, which results in consistently high superovulatory responses with minimum variation between animal. Furthermore the development of persistent follicles is highly undesirable because it compromises fertilisation, leads to premature activation of the oocyte and suboptimal conditions in the oviduct / uterine environments all of which leads to premature embryo recovery rate, embryo quality and subsequent embryo survival.

The ovulation rate within the MOET Technique can be said as superovulation if the donor produced $\geq 3$ ovulation following treatment with gonadotrophin. In the present study the percent of animal showed superovulation following first induction was $100 \%$. However, the incidence of superovulatory animal was gradually decreased following succeeding times. The interval between successive stimulation with PMSG was about a month within this study. There is also evidence of poorer responses at subsequent treatments with PMSG (Saumande and Chupin, 1977; McKelvey and Robinson, 1986) probably as a result of production of antibodies against PMSG (Jainudeen et al., 1966). There were incidences of cyst formation in the donor goats. Moreover, each time the embryos were flushed with surgical procedure. There is evidence that surgical flushing result in lower ovulation rate (Fukui et al., 1985; Torres and Sevellee, 1987). The lower ovulation rate could be due to difficulty in seeing the whole surface of the ovary due to adhesion following laparotomy or could also due to tissue damage or infection.

In the present study, the mean ovulation rate was $13.6 \pm 3.6$ (s.e.), $10.5 \pm 8.5$ (s.e.) and $3.5 \pm 3.2$ (s.e.) respectively following $1 \mathrm{st}, 2 \mathrm{nd}$ and $3 \mathrm{rd}$ stimulation. The ovulation rate is satisfactory. This ovulation rate is comparable to that of other researchers within the same breed following induction with PMSG (Biswas et al., 2000) and in other breed (Armstrong et al., 1983a, Agrawal 1986, Cameron et al., 1988), although they used relatively higher doses for superovulation. Here the breed difference could be override by the hormone stimulation. The ovulation rate in the present study is higher in 1st and 2nd flush compare to some of the published works (Riesenberg et al., 2001, Eiamvita Yakorn et al., 1988, Doijode et al., 1992). Although the breed difference could be a possible cause, however there could be also variation in FSH and LH ratio within the PMSG in different batches and lots of PMSG produced in different laboratory. Increase in LH ratio compare to FSH could interfere with the ovulation rate in superovulatory process. Moreover, Riesenberg et al. (2001) used comparatively high dose compare to this experiment. Black Bengal breed is prolific, the mean ovulation rate is two. It has been observed that prolific breed response more compare to non-prolific breed (Fernie et al., 1993). Even then care should be taken for explanation of high ovulation rate in this experiment, as the numbers of animals were small.

Three dose units $900 \mathrm{IU}, 800 \mathrm{IU}$ and $700 \mathrm{IU}$ were used to induce the superovulation. The response was better with $900 \mathrm{IU}$ (13.6 \pm 3.6$)$. However, it was not possible to compare the results with different doses using significant test. Since the number in successive induction, which responded was very lower. Therefore, more works need to standardize the dose effects.

Success of multiple ovulation and embryo transfer process depend not only the superovulation rate but also on the embryo recovery rate and quality of embryo. Surgical procedure was used to flush the embryos in this experiment. The embryo recovery rate was very lower in this experiment and lowered to some of the published works, which were flushed with surgical procedure (Tervit, 1983, 1986, Patil, 1984 and Baril, 1989). The embryo recovery rate varied from $0-100 \%$ in individual cases. The explanation for lower recovery rate could many. Although there were available literatures about the surgical flushing of embryos in other species, however the literature for such flush in goat was not able to find out. The Black Bengal goat is a dwarf breed and there is a lot of subcutaneous fat, which interfered to exteriorize the uterus through the small incision, resulting in disruption of some of the embryos. Moreover during first time flush there were limitations with the embryologist. PMSG was used to induce superovulation, which could result in premature embryo production and lower embryo recovery rate. In this experiment it seems that problem with the flushing and limitation of the embryologist could be the possible cause for lower response because in the subsequent flush with the advance of time (during 3rd flushing) the embryo recovery percentage was increased compare to first and second flush.

Percent of embryos fertilized in this experiment was $100 \%$. Both natural service and artificial insemination were used to fertilize the embryos. This could the possible explanation for 100 percent fertilization rate of the number of embryos recovered.

In this study the embryos were recovered in Day 7 in flush I and flush III and Day 6 in flush II. In flush II there were two early morula. During flush I due to heavy subcutaneous fat it was difficult to take out the entire 
reproductive tract through the incision and it interfered the whole flush from tip to bifurcation of the horn. Therefore in second time the embryos were flushed on Day 6, thinking that embryos will be near the tip or middle of horn so that entire embryos will be able to flush out. Although it increased the embryo recovery rate compare to first time flush, however, 2 embryos were in early stage morula.

Regarding the embryo transfer, in flush I and flush III it was not possible to transfer the embryo due to unavailability of recipients correspond to donor or the recipient were there, but it was not possible to recover any embryo from the correspond donor. In flush two 3 embryos were transferred in one recipient, 2 in right horn and 1 in left horn. However, during exteriorization of the horn of recipient- the CL was destroyed. Therefore the recipient showed heat within 3 weeks.

\section{ACKNOWLEDGEMENT}

The authors acknowledge the financial support of Bangladesh Agricultural University Research System (BAURES) to conduct the research.

\section{REFERENCES}

1. Agrawal KP (1986). Hormonal control of ovulation and induction of superovulation in Barbari goats used as donors in embryo transplantation studies. Indian Journal of Animal Reproduction 7: 81-83.

2. Agrawal KP and Bhattacharyya NK (1982). Non-surgical transplantation of embryo in goats. III International Conference on Goat Production and Diseases, Tuckson-Arizons, USA, January, 10-15.

3. Alam MGS, Ghosh A, Ahmed JU, and Mondal SK (1989). Synchronization of oestrus with "Cloprostenol" in Black Bengal Goat (Capra hircus). Bangladesh Journal of Animal Science 18: 15-21.

4. Armstrong DT and Evan G (1983). Factors influencing success of embryo transfer in sheep and goats. Theriogenology 19: 31-42.

5. Armstrong DT, Pfitzner AP, Warns GM and Seamark RF (1983a). Superovulation treatments and embryo transfer in Angora goats. Journal of Reproduction and Fertility 67: 403 - 410.

6. Armstrong DT, Pfitzner AP, Warns GM and Seamark RF (1983b). Endocrine response of goat after induction of superovulation with PMSG and FSH. Journal of Reproduction and Fertility 67: 395-401.

7. Bari F, Khalid M, Haresign W, Merrel B, Murray A and Richards RIW (1999). An evaluation of the success of MOET in two hill sheep maintained under normal systems of hill flock management. Animal Science 69: 367-376.

8. Baril G, Casamitjana P and Perrin J (1989). Embryo production, freezing and transfer in angora, alpine and saanen goats. Zuchthyg 24: 101.

9. Baril G, Casamitjana P, Perrin J and Vallet JC (1988). Embryo production, freezing and transfer in angora, alpine and saanen goats. 4e Reunion AETE Lyon: 67-93.

10. Biswas S, Ghosh BB, Bandyopadhyay SK, Roy MM and Senapati PK (2000). Response of Buserelin (GnRH) on synchronization of oestrus and multiovulation in Black Bengal goat treated with PMSG and $\mathrm{PGF}_{2} \alpha$. Journal of Interacademicia 4: 290-293.

11. Bondurant RH (1986). Embryo transfer in sheep and goat. In: Current Therapy in Theriogenology. Morrow David A. (Ed). W. B. Saunders Company, Philadelphia. pp 63-66.

12. Bretzlaff KN, Hill A and Ott RS (1983). Induction of luteolysis in goats with prostaglandin $\mathrm{F}_{2 \alpha}$. American. Journal of Veterinary Research 44: 1162-1164.

13. Cameron AWN, Battye KM, Trounson AO (1988). Time of ovulation in goats (Capra hircus) induced to superovulate with PMSG. Journal of Reproduction and Fertility 83: 747.

14. Doijode SV, Bakshi SA, Pargaonkar DR and Markandeya NM (1992). Synchronization of oestrus, superovulation and recovery embryos in Osmanabadi and Crossbred does. Recent Advances in Goat Production. Nutan Printers in New Delhi, pp. 1258-1261.

15. Eiamvita Yakorn J, Natural NG, Apelo CL (1988). Superovulatory treatment in goats (Capra hircus). Thai Journal of Veterinary Medicine 18: 251-258.

16. Fernie K, Dingwall WS, McKELVEY WAC. \& Fitzsimons J (1993). Superovulation in ewe: The effects of source of gonadotrophin, season, breed and age. Proced. British Society of Animal Production. Paper 59.

17. Flores-Foxworth G (1997). Reproductive Biotechnologies in the Goat. In: Current Therapy in Large Animal Theriogenology. $1^{\text {st }}$ edition, Youngquist, R.S., (ed.) Published by W. B. Saunders company. pp 560-567.

18. Fukui Y, Kano H, Kobayashi M, Tetsura M and Ono H (1985). Response to repeated superovulation treatment in the ewe. Japanese Journal of Animal Reproduction 31: 155-157.

19. Goel AK, Tyagni S and Agrawal KP (1991). Superovulation and embryo recovery in Jamunapari goats using FSH on equine origin. Indian Journal of Animal Reproduction 24: 137-145. 
20. Holtz W and Sohnrey B (1992). Oestrus induction during the anoestrus season in goats by means of intravaginal pessaries or subcutaneous implants. Recent Advances in Goat Production. Procedings of $5^{\text {th }}$ International Conference on Goats held in New Delhi 2-8 March. Pp. 1284-1289.

21. Ishwar AK and Pandey JN (1988) Ovulatory response in Black Bengal goats following gonadotrophin administration. $I V$ Annual Conference of SAPI, Makhdoom, 24-26 September. Pp 58

22. Jainudeen MR, Hafez ESE, Gollnick PD and Moustafa LA (1966). Antigonadotrophins in the serum of cows following repeated therapeutic pregnant mare serum injections. American. Journal of Veterinary Research 27: 669-675.

23. Keys A, Menotti A, Karvoem MJ, Aravanis C, Blackburn H, Buzina R, Djordjevie BS, Dontas AS, Fidanza F, Keys MH, Kromhout D, Nedeljkovie S, Punsar S, Seccareccia F and Toshima H (1986). The diet and 15 year death rate in the seven countries study. American Journal of Epidemiology 124: 903-915.

24. Lewis I (1996). Conventional embryo transfer. In: Ian Lewis, John Owens, sandy McClintock and Melanie Trevean (eds.) Cattle Breeding Technologies. Published by, Genetic Australia, Australia. pp. 48-54.

25. Martemucci G (1992). Superovulation response of FSH-P to different treatments in donor goats. Recent Advan. In goat prod. Proceedings of $5^{\text {th }}$ International Conference on goats held in New Delhi. 2-8 March. Pp.1328-1334.

26. McKelvey WAC and Robinson, JJ. (1986). Repeated recoveries of ovine ova by laparoscopy. Theriogenology 25 : 171.

27. Moor RM and Rowson LEA (1966). Embryo transfer in the sheep: the significance of synchronizing oestrus in the donor and recipient animal. Journal of Reproduction and Fertility 11, 207-212.

28. Nagashima H, Matsui K, Sawasaki T (1987). Non-surgical collection of embryos in Shiba goats. Experimental Animal Science 36: 51 .

29. Nandy DK, Agrawal KP and Bhattacharyya NK (1990). Ovaries response to superovulation in non-descript does. Indian Journal of Animal Science 60: 972-973.

30. Pandey JN and Ishwar AK (1990). Estrus synchronization and fertility behaviour in Black Bengal goats follows progesterone and prostaglandin treatment. Theriogenology 34: 1015-1024.

31. Pandiya SC and Rathor (1986). Embryo transfer in goats. Indian Veterinary Journal 63: 34-36.

32. Patil VK, Bakshi SA and Zanwar SG (1984). Embryo transfer in goats- synchronization, superovulation and Recovery of embryos. Paper presented in International Symposium on Foetal Biology held at college of Veterinary Science, and Animal Husbandry, CSA University of Agriculture and Technology, Mathura (India) from Feb. 20-23.

33. Perera BMA, Bongso TA and Abeynaike P (1978). Estrus synchronization in goats using cloprostenol. Veterinary Record 102: 314 abstract.

34. Riesenberg S, Meinecke-Tillmann S and Meinecke B (2001). Ultrasonic survey of follicular development following superovulation with a single application of pFSH, eCG or hMG in goats. Small Ruminant Research 40: 83-93.

35. Saumande J and Chupin D (1977). Superovulation: a limit to egg transfer in cattle. Theriogenology 7: 141-149.

36. Smith C (1986). Use of embryo transfer in genetic improvement of sheep. Animal Production 42: 81-88.

37. Tervit HR, Goold PG and McKensie RD (1986). Development of an effective goat embryo transfer regime. Proceeding New Zealand Society of Animal Production 46: 233.

38. Tervit HR, Goold PG, McKenzie RD and Clarkson DJ (1983). Techniques and success of embryo transfer in angora goats. New Zealand Veterinary Journal 31: 67-70.

39. Torres S and Sevellee C (1987). Repeated superovulation and surgical recovery of embryos in the ewes. Reproduction, Nutrition and Development 27: 859-863.

40. Torres S, Cognie Y and Colas G (1987). Transfer of superovulated sheep embryos obtained with different FSH-P. Theriogenology 27: 407-419. 